\title{
Effects of Methanol Extract of Breadfruit (Artocarpus altilis) on Atherogenic Indices and Redox Status of Cellular System of Hypercholesterolemic Male Rats
}

\author{
Oluwatosin Adekunle Adaramoye and Olubukola Oyebimpe Akanni \\ Drug Metabolism and Toxicology Research Laboratories, Department of Biochemistry, College of Medicine, \\ University of Ibadan, Ibadan 20005, Nigeria \\ Correspondence should be addressed to Oluwatosin Adekunle Adaramoye; aoadaramoye@yahoo.com
}

Received 23 November 2013; Revised 17 December 2013; Accepted 18 December 2013; Published 30 January 2014

Academic Editor: Neal Davies

Copyright (C) 2014 O. A. Adaramoye and O. O. Akanni. This is an open access article distributed under the Creative Commons Attribution License, which permits unrestricted use, distribution, and reproduction in any medium, provided the original work is properly cited.

\begin{abstract}
We investigated the effects of methanol extract of Artocarpus altilis (AA) on atherogenic indices and redox status of cellular system of rats fed with dietary cholesterol while Questran (QUE) served as standard. Biochemical indices such as total cholesterol (TC), triglycerides (TG), low- and high-density lipoproteins-cholesterol (LDL-C and HDL-C), aspartate and alanine aminotransferases (AST and ALT), lactate dehydrogenase (LDH), reduced glutathione, glutathione-s-transferase, glutathione peroxidase (GPx), catalase (CAT), superoxide dismutase (SOD), and lipid peroxidation (LPO) were assessed. Hypercholesterolemic (HC) rats had significantly increased relative weight of liver and heart. Dietary cholesterol caused a significant increase $(P<0.05)$ in the levels of serum, hepatic, and cardiac TC by $110 \%, 70 \%$, and $85 \%$, LDL-C by $79 \%, 82 \%$, and $176 \%$, and TG by $68 \%, 96 \%$, and $62 \%$, respectively. Treatment with AA significantly reduced the relative weight of the organs and lipid parameters. There were beneficial increases in serum and cardiac HDL-C levels in HC rats treated with AA. In HC rats, serum LDH, ALT, and AST activities and levels of LPO were increased, whereas hepatic and cardiac SOD, CAT, and GPx were reduced. All biochemical and histological alterations were ameliorated upon treatment with AA. Extract of AA had protective effects against dietary cholesterol-induced hypercholesterolemia.
\end{abstract}

\section{Introduction}

Recent studies have demonstrated that increased formation of free radicals/reactive oxygen species (ROS) contributes to cardiovascular disease (CVD) progression [1]. Generation of large amounts of ROS can overwhelm the intracellular antioxidant defense, causing lipid peroxidation, protein modification, and DNA breaks [2]. It is known that ROS-induced depletion of antioxidants is a key factor for the initiation of atherosclerosis and the development of CVD [3]. Hypercholesterolemia, characterized by the presence of high levels of cholesterol in the blood [4], is a form of hyperlipidemia and hyperlipoproteinemia. Hyperlipidemia has also been found to induce oxidative stress in various organs of the body [5]. Although several factors, such as life style, a diet rich in cholesterol, and age, have been reported to cause heart failure [6, 7], high levels of cholesterol, particularly LDLcholesterol, are mainly responsible for hypercholesterolemia [8]. Drugs that lower cholesterol such as fibrates and bile acid sequestrants were used for several decades, but the high prevalence of adverse effects led to the introduction of statins (HMG-CoA inhibitors) [9]. Although the adverse effect of statins is relatively low, one rare effect called rhabdomyolysis can be very serious with statins [9]. In view of these adverse effects, the quest for natural products with hypolipidemic potential and minimal side effect is warranted.

Breadfruit (Artocarpus altilis) is a flowering tree in the mulberry family. The fruit can be eaten once cooked or can be further processed into a variety of other foods. It is an excellent source of fiber, calcium, copper, iron, magnesium, potassium, thiamine, niacin, carbohydrates, and vitamins and very low in fat [10]. In herbal homes, leaves of this plant 
are used for the treatment of liver disorders, hypertension, and diabetes [11, 12]. In vitro studies by Nwokocha et al. [13] supported the folkloric use of this plant. However, little information is available with respect to in vivo studies on its ethnomedicinal uses. This study was designed to evaluate the effects of Artocarpus altilis on atherogenic indices and redox status of cellular system of hypercholesterolemic rats.

\section{Materials and Methods}

2.1. Chemicals. Questran (Bristol-Myers Squibb, Hounslow, UK) was purchased from a local chemist in Ibadan, Nigeria. Dietary cholesterol and thiobarbituric acid (TBA) were procured from Aldrich Chemical Co. (Milwaukee, WI, USA). Glutathione, hydrogen peroxide, 5, $5^{\prime}$-dithio-bis2-nitrobenzoic acid (DNTB), and epinephrine were purchased from Sigma Chemical Co., Saint Louis, MO, USA. Trichloroacetic acid (TCA) and thiobarbituric acid (TBA) were purchased from British Drug House (BDH) Chemical Ltd., Poole, UK. Other reagents were of analytical grade and the purest quality available.

2.2. Collection and Extraction of Artocarpus altilis. The stem bark of Artocarpus altilis was collected in Ibadan (Oyo State) and authenticated at the Botanical Garden of the University of Ibadan. The stem bark of Artocarpus altilis was air-dried and crushed into fine powder. The powdered part was extracted with n-hexane and methanol using soxhlet extractor and the extract was concentrated in vacuum at $40^{\circ} \mathrm{C}$ with rotary evaporator and water bath to dryness. The yield of the extraction was $5.7 \%$.

2.3. Determination of Total Phenolic Contents. The total phenolic content of the extract was determined using the method of Singleton et al. [14] with slight modifications. Folin-C reagent $(1 \mathrm{~mL})$ was added to $1 \mathrm{~mL}$ of extract or standard. After 3 minutes, $1 \mathrm{~mL}$ of $15 \% \mathrm{Na}_{2} \mathrm{CO}_{3}$ was added and the solution was made up to $5 \mathrm{~mL}$ with distilled water. The reaction mixture was kept in the dark for 90 minutes with intermittent shaking or placed in a water bath at $40^{\circ} \mathrm{C}$ for 20 minutes. The absorbance was measured by a Beckman DU (70) Spectrophotometer at $760 \mathrm{~nm}$. All experiments were done in triplicate. A standard curve was plotted with catechin and the phenolic content expressed as CE (catechin equivalent) per mg dry weight of the extract.

2.3.1. DPPH-Radical Scavenging Activity. The radical scavenging activity of the extract was measured as described by Mensor et al. [15]. The stable 2,2-diphenyl-1-picrylhydrazyl $(\mathrm{DPPH})$ radical was used for the determination of free radical scavenging activities of the extracts. A portion $(1 \mathrm{~mL})$ of each of the different concentrations $(10-1000 \mu \mathrm{g} / \mathrm{mL})$ of the extracts or standard (catechin) was added to $1 \mathrm{~mL}$ of $1 \mathrm{mM}$ DPPH in methanol. The mixtures were vortexed and incubated in a dark chamber for 30 minutes after which the absorbance was measured at $517 \mathrm{~nm}$ against a DPPH control containing only $1 \mathrm{~mL}$ of methanol in place of the extract. All calculations were carried out in triplicates. The inhibition of $\mathrm{DPPH}$ was calculated as a percentage using the expression

$$
I \%=\frac{A_{\text {control }}-A_{\text {sample }}}{A_{\text {control }}} \times 100,
$$

where $I \%$ is the percentage inhibition of the DPPH radical, $A_{\text {control }}$ is the absorbance of the control, and $A_{\text {sample }}$ is the absorbance of the test compound.

2.4. Animals. Inbred male Wistar rats weighing between 150 and $180 \mathrm{~g}$ were purchased from the animal house of the Department of Veterinary Physiology, Biochemistry, and Pharmacology, University of Ibadan, Nigeria. Animals were kept in ventilated cages at room temperature $\left(28-30^{\circ} \mathrm{C}\right)$ and maintained on normal laboratory chow (Ladokun Feeds, Ibadan, Nigeria) and water ad libitum. Rats handling and treatments conform to guidelines of the National Institute of Health (NIH publication 85-23, 1985) for laboratory animal care and use. The study was approved by the Faculty of Basic Medical Sciences, University of Ibadan Animal Ethics Committee.

2.5. Study Design. Thirty-five male rats were randomly divided into seven groups of five rats each. The first group (control) received drug vehicle (corn oil), the second group (HC) received dietary cholesterol at $30 \mathrm{mg} / 0.3 \mathrm{~mL}$ [16], the third group ( $\mathrm{HC}+\mathrm{AA} 1)$ received dietary cholesterol and Artocarpus altilis $(100 \mathrm{mg} / \mathrm{kg})$, the fourth group (HC + AA2) received dietary cholesterol and Artocarpus altilis $(200 \mathrm{mg} / \mathrm{kg})$, the fifth group (HC + QUE) received dietary cholesterol and Questran $(0.26 \mathrm{~g} / \mathrm{kg})$ [16], the sixth group (QUE) received questran alone, and the seventh group (AA) received Artocarpus altilis at a dose of $200 \mathrm{mg} / \mathrm{kg}$ body weight.

2.6. Preparation of Tissues. Rats were fasted overnight and sacrificed 24 hours after the last dose of drugs. Liver and heart were quickly removed and washed in ice-cold 1.15\% $\mathrm{KCl}$ solution, dried, and weighed. A section of liver and aorta samples were fixed in $10 \%$ formalin for histological examination. The remaining parts of liver and heart were homogenized in 4 volumes of $50 \mathrm{mM}$ phosphate buffer, $\mathrm{pH}$ 7.4 , and centrifuged at $10,000 \mathrm{~g}$ for 15 minutes to obtain postmitochondrial supernatant fraction (PMF). All procedures were carried out at temperature of $0-4^{\circ} \mathrm{C}$.

2.6.1. Preparation of Serum. Blood was collected from the heart of the animals into plain centrifuge tubes and was allowed to stand for 1 hour. Serum was prepared by centrifugation at $3,000 \mathrm{~g}$ for 15 minutes in a Beckman bench centrifuge. The clear supernatant was used for the estimation of serum lipid profile and enzymes.

2.7. Biochemical Assays. Protein contents of the samples were assayed by the method of Lowry et al. [17] using bovine serum albumin as standard. The activities of alanine and aspartate aminotransferases (ALT and AST) were assayed by the combined methods of Mohun and Cook [18] and Reitman 
TABLE 1: Changes in the body weight and relative weight of organs of hypercholesterolemic rats treated with methanol extract of Artocarpus altilis for nine weeks.

\begin{tabular}{|c|c|c|c|c|c|c|c|c|}
\hline \multirow{2}{*}{ Treatment } & \multicolumn{2}{|c|}{ Body weight (g) } & \multicolumn{3}{|c|}{ Weight of organs (g) } & \multicolumn{3}{|c|}{ Relative weight of organs } \\
\hline & Initial & Final & Liver & Kidney & Heart & Liver & Kidney & Heart \\
\hline Control & $151.00 \pm 4.94$ & $194.00 \pm 23.02$ & $5.38 \pm 0.49$ & $1.03 \pm 0.11$ & $0.53 \pm 0.09$ & $2.77 \pm 0.75$ & $0.53 \pm 0.05$ & $0.27 \pm 0.04$ \\
\hline $\mathrm{HC}$ & $160.00 \pm 3.10$ & $198.00 \pm 29.03$ & $6.89 \pm 0.89$ & $1.09 \pm 0.14$ & $0.69 \pm 0.06$ & $3.48 \pm 0.23^{*}$ & $0.55 \pm 0.03$ & $0.39 \pm 0.02^{*}$ \\
\hline $\mathrm{HC}+\mathrm{AA} 1$ & $159.00 \pm 5.48$ & $196.00 \pm 37.15$ & $5.12 \pm 1.22$ & $1.09 \pm 0.20$ & $0.55 \pm 0.08$ & $2.61 \pm 0.13^{* *}$ & $0.56 \pm 0.04$ & $0.28 \pm 0.03^{* *}$ \\
\hline $\mathrm{HC}+\mathrm{AA} 2$ & $167.00 \pm 6.04$ & $185.00 \pm 45.00$ & $5.20 \pm 1.24$ & $1.09 \pm 0.20$ & $0.52 \pm 0.09$ & $2.81 \pm 0.15^{* *}$ & $0.59 \pm 0.06$ & $0.28 \pm 0.04^{* *}$ \\
\hline $\mathrm{HC}+\mathrm{QUE}$ & $173.00 \pm 4.74$ & $202.50 \pm 5.00$ & $5.39 \pm 1.05$ & $1.19 \pm 0.07$ & $0.55 \pm 0.01$ & $2.66 \pm 0.43^{* *}$ & $0.59 \pm 0.05$ & $0.27 \pm 0.01^{* *}$ \\
\hline QUE & $188.00 \pm 3.95$ & $225.00 \pm 20.41$ & $5.06 \pm 1.21$ & $1.17 \pm 0.05$ & $0.51 \pm 0.49$ & $2.24 \pm 0.41$ & $0.52 \pm 0.07$ & $0.23 \pm 0.04$ \\
\hline $\mathrm{AA} 2$ & $192.00 \pm 8.34$ & $235.00 \pm 22.36$ & $5.19 \pm 0.55$ & $1.21 \pm 0.11$ & $0.62 \pm 0.06$ & $2.21 \pm 0.17$ & $0.52 \pm 0.04$ & $0.26 \pm 0.03$ \\
\hline
\end{tabular}

Values are means \pm SD of 5 animals per group; HC: cholesterol at $30 \mathrm{mg} / 0.3 \mathrm{~mL}$.

AA1: Artocarpus altilis at $100 \mathrm{mg} / \mathrm{kg}$, AA2: Artocarpus altilis at $200 \mathrm{mg} / \mathrm{kg}$, and QUE: Questran at $0.26 \mathrm{~g} / \mathrm{kg}$.

${ }^{*}$ Significantly different from control $(P<0.05),{ }^{* *}$ significantly different from $\mathrm{HC}(P<0.05)$.

and Frankel [19]. Serum total cholesterol level was assayed by the method of Richmond [20]. The method involved enzymatic hydrolysis and oxidation of cholesterol with the formation of quinoneimine (an indicator) from hydrogen peroxide and 4-aminoantipyrine in the presence of phenol and peroxide. The serum level of triglyceride was determined by Jacobs and van Demark [21] and Koditschek and Umbreit [22]; this was based on the hydrolysis of triglycerides with the formation of glycerol which is substrate for other enzymes with the subsequent formation of hydrogen peroxide. This then reacts with 4-aminophenazone and 4-chlorophenol in the presence of peroxidase to give quinoneimine which is measured spectrophotometrically at $500 \mathrm{~nm}$.

The lipoproteins (measured using the enzymatic colorimetric method), very low-density lipoprotein (VLDL) and low-density lipoprotein (LDL), were precipitated by the addition of phosphotungstic acid and magnesium chloride. After centrifugation at $3,000 \mathrm{~g}$ for 10 minutes at $25^{\circ} \mathrm{C}$, the clear supernatant contained HDL fraction, which was assayed for cholesterol with the Randox diagnostic kit. The lowdensity lipoprotein (LDL) was calculated using the formula of Friedewald et al. [23]. Lipid peroxidation level was assayed by the reaction between 2-thiobarbituric acid (TBA) and malondialdehyde (MDA), an end product of lipid peroxides as described by Buege and Aust [24].

The activity of lactate dehydrogenase (LDH) was determined by the method of Zimmerman and Weinstein [25], while tissue superoxide dismutase (SOD) activity was measured by the nitro blue tetrazolium (NBT) reduction method of McCord and Fridovich [26]. Catalase (CAT) activity was assayed spectrophotometrically by measuring the rate of decomposition of hydrogen peroxide at $240 \mathrm{~nm}$ as described by Aebi [27]. Reduced glutathione level was measured by the method of Beutler et al. [28]; this method is based on the development of a relatively stable (yellow) colour when $5^{\prime}, 5^{\prime}$ dithiobis-(2-nitrobenzoic acid) (Ellman's reagent) is added to sulfhydryl compounds. The chromophoric product resulting from the reaction of Ellman's reagent with the reduced glutathione (2-nitro-5-thiobenzoic acid) possesses a molar absorption at $412 \mathrm{~nm}$ which is proportion to the level of reduced glutathione in the test sample. The glutathione peroxidase (GPx) activity was assessed by the method of Rotruck et al. [29], while glutathione-S-transferase (GST) activity was determined according to Habig et al. [30]; the principle is based on the fact that all of known GST demonstrates a relatively high activity with 1-chloro-2,4-dinitrobenzene as the second substrate. When this substance is conjugated with reduced glutathione, its absorption maximum shifts to a longer wavelength $340 \mathrm{~nm}$ and the absorption increase at this wavelength provides a direct measurement of the enzymatic reaction.

2.7.1. Determination of Antiatherogenic, Cardioprotective, and Coronary Risk Indices. Cardioprotective index (CPI) was estimated in terms of HDL-C to LDL-C ratio [31, 32], whereas antiatherogenic (AAI) and coronary risk indices (CRI) were calculated by the following formulae $[33,34]$ :

$$
\begin{gathered}
\text { AAI }=100 \times \frac{[\text { HDL-C }]}{[\text { Total cholesterol }- \text { HDL-C }]}, \\
\text { CRI }=\frac{\text { Total cholesterol }}{\text { HDL-cholesterol }} .
\end{gathered}
$$

2.8. Histopathology of Tissues. Tissues fixed in $10 \%$ formalin were dehydrated in $95 \%$ ethanol and then cleared in xylene before embedded in paraffin. Microsections (about $4 \mu \mathrm{m}$ ) were prepared and stained with haematoxylin and eosin (H\&E) dye and were examined under a light microscope by a histopathologist who was ignorant of the treatment groups.

2.9. Statistical Analysis. All values were expressed as the mean \pm SD of five animals per group. Data were analyzed using one-way ANOVA followed by the post hoc Duncan multiple range test for analysis of biochemical data using SPSS (10.0). Values were considered statistically significant at $P<0.05$.

\section{Results}

3.1. Phenolic and Flavonoids Contents and Effects of Artocarpus altilis on Body Weight and Relative Weight of Organs of Hypercholesterolemic (HC) Rats. In Table 1, there were significant increases $(P<0.05)$ in the relative weight of liver 
TABLE 2: The total phenolic contents and scavenging activity of Artocarpus altilis on 2,2-diphenyl-1-picrylhydrazyl radical (DPPH) in vitro.

\begin{tabular}{lccc}
\hline $\begin{array}{l}\text { Conc. } \\
(\mu \mathrm{g} / \mathrm{mL})\end{array}$ & \multicolumn{2}{c}{$\begin{array}{c}\text { \% Scavenging activity } \\
\text { Catechin }\end{array}$} & $\begin{array}{c}\text { Phenolic content } \\
(\mu \mathrm{g} \mathrm{CE} / \mathrm{mg})\end{array}$ \\
\hline 100 & $42.2 \pm 4.4$ & $22.7 \pm 5.9$ & $0.18 \pm 0.02$ \\
300 & $47.6 \pm 1.6$ & $50.4 \pm 3.1$ & $0.39 \pm 0.03$ \\
500 & $63.1 \pm 5.1$ & $51.1 \pm 2.3$ & $0.52 \pm 0.07$ \\
750 & $67.8 \pm 3.9$ & $62.5 \pm 8.5$ & $0.68 \pm 0.05$ \\
\hline
\end{tabular}

Data are expressed as mean $\pm \operatorname{SD}(n=4)$.

AA: Artocarpus altilis.

and heart of $\mathrm{HC}$ rats when compared with the control, while treatment with AA (100 and $200 \mathrm{mg} / \mathrm{kg}$ ) significantly reduced the relative weight of heart and liver of $\mathrm{HC}$ rats to values that were statistically similar $(P>0.05)$ to the control. Similar reduction was obtained in questran-treated $\mathrm{HC}$ rats. The total phenolic contents (TPC) of AA expressed in $\mu \mathrm{g}$ catechin equivalent per mg dry weight of the extract increased with increase in concentration (Table 2). At $750 \mu \mathrm{g} / \mathrm{mL}$, the TPC of AA was $0.68 \pm 0.05 \mu \mathrm{g} \mathrm{CE} / \mathrm{mg}$. There were significant $(P<0.05)$ and dose-dependent increases in scavenging activity of AA on DPPH radicals (Table 2). At $100 \mu \mathrm{g} / \mathrm{mL}$ and $750 \mu \mathrm{g} / \mathrm{mL}$, the percentage $\mathrm{DPPH}$ radical scavenging activities of AA were $42.2 \%$ and $67.8 \%$, respectively.

3.2. Effects of Artocarpus altilis on Antioxidant Parameters and Marker Enzymes in Hypercholesterolemic (HC) Rats. Administration of dietary cholesterol significantly increased $(P<0.05)$ serum, hepatic, and cardiac lipid peroxidation (LPO) products measured as thiobarbituric acid reactive substances (TBARS) by $265 \%, 83 \%$, and $80 \%$, respectively (Table 3). However, treatment with AA completely ameliorated dietary cholesterol-induced increase in LPO. In HC rats, the activities of hepatic, and cardiac SOD and CAT as well as cardiac GPx decreased significantly relative to the control (Table 4). Specifically, hepatic SOD and CAT decreased by $54 \%$ and $45 \%$, while cardiac SOD, CAT, and GPx decreased by $67 \%, 59 \%$, and $36 \%$, respectively. Also, activities of phase II and antioxidant enzyme (GST) in the liver of HC rats were significantly reduced when compared to controls (Figure 5). Administration of AA (200 mg/kg) reversed the adverse effect of high dietary cholesterol by normalizing these enzymic antioxidant indices. In HC rats, serum ALT, AST and LDH were significantly increased by 2.3-, 1.7-, and 2.4fold, respectively, while cardiac LDH activity was decreased by 3.0-fold relative to controls (Table 5 and Figures 3 and 4). However, the observed elevations in the activities of these serum enzymes in $\mathrm{HC}$ rats were reversed following treatment with AA and quetsran.

3.3. Effects of Artocarpus altilis on the Lipid Profile of Hypercholesterolemic Rats. Feeding rats on high dietary cholesterol for nine consecutive weeks significantly $(P<0.05)$ increased the serum, hepatic, and cardiac total cholesterol levels by $110 \%, 70 \%$, and 85\%, respectively (Table 6 and Figures 1 and 2). Furthermore, serum, hepatic, and cardiac triglycerides increased by $68 \%, 96 \%$, and $62 \%$, while serum LDL-C

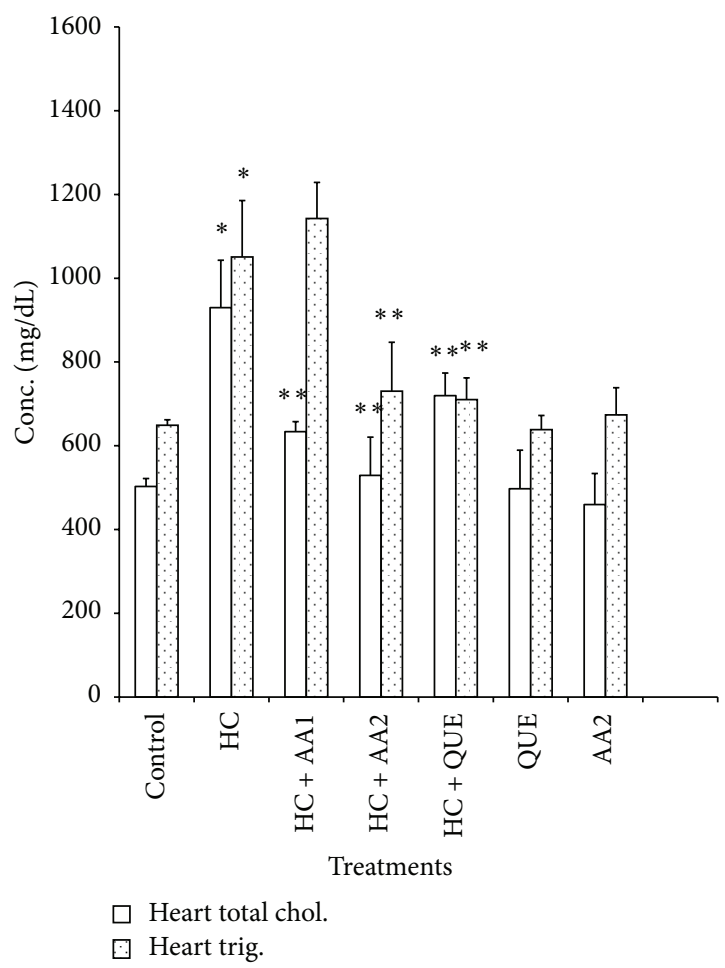

FIgURE 1: Effects of methanol extract of Artocarpus altilis and Questran on cardiac total cholesterol and triglyceride levels of hypercholesterolemic rats. ${ }^{*}$ Significantly different from control $(P<$ $0.05),{ }^{* *}$ significantly different from HC $(P<0.05)$. HC: Hypercholesterolemic rats, AA1: Artocarpus altilis at $100 \mathrm{mg} / \mathrm{kg}$, AA2: Artocarpus altilis at $200 \mathrm{mg} / \mathrm{kg}$, and QUE: Questran at $0.26 \mathrm{~g} / \mathrm{kg}$.

increased by 79\%, respectively, in $\mathrm{HC}$ rats relative to controls. In addition, $\mathrm{HC}$ rats had significantly lower $\mathrm{HDL}-\mathrm{C}$ values when compared to the control (Table 6). Administration of $\mathrm{AA}$ at $200 \mathrm{mg} / \mathrm{kg}$ attenuated the elevated levels of these lipid indices to near normal in the tissues of $\mathrm{HC}$ rats. The protective effect of AA at $200 \mathrm{mg} / \mathrm{kg}$ seems better than the standard hypolipidemic drug (Questran). Furthermore, AA increased serum antiatherogenic index in HC rats, while coronary risk index was decreased (Table 7).

3.4. Effects of Artocarpus altilis on the Histology of Aorta and Liver. The histology of liver slide showed marked portal congestion, severe periportal cellular infiltration by mononuclear cells, and mild diffuse vacuolar degeneration of hepatocytes (Figure 6), while aorta from $\mathrm{HC}$ rats revealed large focal area of myofibril necrosis with severe hemorrhages and fibrous connective tissue laid down (Figure 7). Treatment with AA $(200 \mathrm{mg} / \mathrm{kg})$ reversed the adverse effect of high dietary cholesterol on the histological architecture of the aorta and liver of the rats. The histological results further corroborated the biochemical findings indicating the beneficial effects of $\mathrm{AA}$ in hypercholesterolemic rats.

\section{Discussion}

It is generally known that elevation of serum LDL-C and total cholesterol (TC) can lead to CVD, especially atherosclerosis. 
TABLE 3: Changes in the levels of lipid peroxidation in hypercholesterolemic rats treated with methanol extract of Artocarpus altilis for nine weeks.

\begin{tabular}{lccc}
\hline Treatments & $\begin{array}{c}\text { Liver } \\
(\mu \mathrm{mol} \mathrm{MDA} / \mathrm{mg} \text { protein })\end{array}$ & $\begin{array}{c}\text { Heart } \\
(\mu \mathrm{mol} \mathrm{MDA} / \mathrm{mg} \text { protein })\end{array}$ & $\begin{array}{c}\text { Serum } \\
(\mu \mathrm{mol} \mathrm{MDA} / \mathrm{mg} \text { protein })\end{array}$ \\
\hline Control & $0.06 \pm 0.01$ & $0.15 \pm 0.02$ & $1.32 \pm 0.24$ \\
HC & $0.11 \pm 0.02^{*}$ & $0.27 \pm 0.03^{*}$ & $4.82 \pm 0.68^{*}$ \\
HC + AA1 & $0.08 \pm 0.03^{* *}$ & $0.13 \pm 0.03^{* *}$ & $2.63 \pm 0.56^{* *}$ \\
HC + AA2 & $0.07 \pm 0.02^{* *}$ & $0.14 \pm 0.03^{* *}$ & $2.04 \pm 0.35^{* *}$ \\
HC + QUE & $0.08 \pm 0.02$ & $0.15 \pm 0.02$ & $2.85 \pm 0.77$ \\
QUE & $0.05 \pm 0.01$ & $0.16 \pm 0.07$ & $1.82 \pm 0.60$ \\
AA2 & $0.07 \pm 0.01$ & $0.15 \pm 0.02$ & $1.16 \pm 0.33$ \\
\hline
\end{tabular}

Values are means \pm SD of 5 animals per group; HC: cholesterol at $30 \mathrm{mg} / 0.3 \mathrm{~mL}$.

AA1: Artocarpus altilis at $100 \mathrm{mg} / \mathrm{kg}$, AA2: Artocarpus altilis at $200 \mathrm{mg} / \mathrm{kg}$, and QUE: Questran at $0.26 \mathrm{~g} / \mathrm{kg}$.

${ }^{*}$ Significantly different from control $(P<0.05),{ }^{* *}$ significantly different from $\mathrm{HC}(P<0.05)$.

TABLE 4: Changes in the levels of hepatic and cardiac antioxidant parameters in hypercholesterolemic rats treated with methanol extract of Artocarpus altilis for nine weeks.

\begin{tabular}{|c|c|c|c|c|c|c|c|c|}
\hline \multirow{3}{*}{ Treatment } & \multicolumn{4}{|c|}{ Liver } & \multicolumn{4}{|c|}{ Heart } \\
\hline & GSH & GPx & SOD & CAT & $\mathrm{GSH}$ & GPx & SOD & CAT \\
\hline & \multicolumn{2}{|c|}{ (mg/g tissue) } & \multicolumn{2}{|c|}{ (U/mg protein) } & \multicolumn{2}{|c|}{ (mg/g tissue) } & \multicolumn{2}{|c|}{ (U/mg protein) } \\
\hline Control & $0.85 \pm 0.15$ & $5.55 \pm 0.83$ & $7.36 \pm 1.01$ & $5.57 \pm 1.08$ & $21.06 \pm 1.11$ & $145.74 \pm 5.74$ & $0.03 \pm 0.01$ & $5.37 \pm 0.81$ \\
\hline $\mathrm{HC}$ & $0.73 \pm 0.01$ & $4.92 \pm 0.08$ & $3.40 \pm 0.69^{*}$ & $3.04 \pm 0.05^{*}$ & $19.25 \pm 0.99$ & $92.82 \pm 2.87^{*}$ & $0.01 \pm 0.01^{*}$ & $2.19 \pm 0.65^{*}$ \\
\hline $\mathrm{HC}+\mathrm{AA} 1$ & $0.92 \pm 0.26$ & $4.98 \pm 0.06$ & $7.26 \pm 1.00^{* *}$ & $5.43 \pm 1.71^{* *}$ & $19.35 \pm 0.85$ & $108.43 \pm 2.87$ & $0.01 \pm 0.01$ & $2.99 \pm 0.74$ \\
\hline $\mathrm{HC}+\mathrm{AA} 2$ & $0.96 \pm 0.25$ & $5.73 \pm 1.50$ & $7.43 \pm 0.71^{* *}$ & $5.55 \pm 1.59^{* *}$ & $20.38 \pm 1.11$ & $137.47 \pm 3.01^{* *}$ & $0.03 \pm 0.00^{* *}$ & $4.03 \pm 0.80^{* *}$ \\
\hline $\mathrm{HC}+\mathrm{QUE}$ & $0.85 \pm 0.12$ & $5.37 \pm 0.99$ & $5.95 \pm 0.24$ & $5.32 \pm 3.90$ & $21.21 \pm 3.10$ & $147.50 \pm 4.81$ & $0.03 \pm 0.01$ & $5.65 \pm 0.74$ \\
\hline QUE & $0.79 \pm 0.08$ & $4.55 \pm 0.69$ & $5.39 \pm 0.86$ & $4.90 \pm 0.59$ & $20.24 \pm 1.66$ & $130.64 \pm 3.39$ & $0.02 \pm 0.00$ & $4.55 \pm 0.90$ \\
\hline AA2 & $0.88 \pm 0.04$ & $5.24 \pm 0.12$ & $6.03 \pm 0.56$ & $5.11 \pm 0.04$ & $20.46 \pm 0.77$ & $144.46 \pm 3.83$ & $0.03 \pm 0.01$ & $3.92 \pm 0.91$ \\
\hline
\end{tabular}

Values are means \pm SD of 5 animals per group; HC: cholesterol at $30 \mathrm{mg} / 0.3 \mathrm{~mL}$.,

AA1: Artocarpus altilis at $100 \mathrm{mg} / \mathrm{kg}$, AA2: Artocarpus altilis at $200 \mathrm{mg} / \mathrm{kg}$, and QUE: Questran at $0.26 \mathrm{~g} / \mathrm{kg}$.

${ }^{*}$ Significantly different from control $(P<0.05),{ }^{* *}$ significantly different from $\mathrm{HC}(P<0.05)$.

Reducing LDL-C and TC can prevent the risk of CVD, a leading cause of mortality worldwide [35]. Appropriate lifestyle changes and pharmacologic approaches have both demonstrated their effectiveness in lowering LDL-C and TC [36], but the negative side effects of the pharmacological intervention have been a major setback. Lifestyle changes to include decreased saturated fats and increased soluble fibre in the diet, weight loss and regular physical activity are primary strategy for preventing CVD. Regular consumption of dietary supplements or functional foods that have demonstrated positive effects on plasma lipid values in randomised placebo-controlled clinical studies can also be considered as part of this CVD prevention strategy [37]. On this basis, we investigated the effects of methanol extract of AA on atherogenic indices and redox status of cellular system in hypercholesterolemic (HC) rats.

The present study clearly shows that feeding rats on high cholesterol diets for nine weeks caused significant increase in relative weight of heart and liver of the rats. This observation is consistent with the findings of Adaramoye et al. [16] and Yuji et al. [38]. However, treatment with AA (100 and $200 \mathrm{mg} / \mathrm{kg}$ ) and Questran significantly reduced the relative weight of liver and heart of the HC rats. In this study, HC rats had high serum, hepatic, and cardiac
TC, TG, and LDL-C when compared to controls. Similar observations on hypercholesterolemic rats were observed by Yuji et al. [38], Adaramoye et al. [39], and, Kamesh and Sumathi [40]. Furthermore, a decrease in serum HDL-C levels was also observed in $\mathrm{HC}$ rats, which actually reflects the lower cholesterol transports by HDL-C in blood from peripheral tissues to liver for its metabolism and excretion [41]. The elevated serum and tissues levels of TC, TG, and LDL-C and lower levels of HDL-C provide a high risk for the development of atherosclerosis and other CVD [42]. In the study, extract of AA significantly decreased the levels of TC, TG, and LDL-C and increased HDL-C in the HC rats as compared to controls. The lipoproteins, especially LDL-C are involved in depositing TC and TG on walls of coronary arteries and initiate the process of atherosclerotic plaques [43]. Reduced serum and tissues levels of TC, TG, and LDL-c found in HC rats treated with doses (100 and $200 \mathrm{mg} / \mathrm{kg}$ ) of AA are among the beneficial aspects of this current research and proved the antiatherosclerotic potential of this extract. The crucial risk factor for CVD includes a low level of HDL$\mathrm{C}$ and high level of LDL-C. The association between a low level of HDL-C and an increased risk of CVD has been well established through epidemiological and clinical studies [44]. Since low level of HDL-C plays a direct role in the 
TABLE 5: Changes in the activities of serum, hepatic, and cardiac alanine and aspartate aminotransferases in hypercholesterolemic rats treated with methanol extract of Artocarpus altilis for nine weeks.

\begin{tabular}{|c|c|c|c|c|c|c|}
\hline \multirow{2}{*}{ Treatments } & \multicolumn{2}{|c|}{ Liver (U/L) } & \multicolumn{2}{|c|}{ Heart (U/L) } & \multicolumn{2}{|c|}{ Serum $(\mathrm{U} / \mathrm{L})$} \\
\hline & AST & ALT & AST & ALT & AST & ALT \\
\hline Control & $610.6 \pm 16.3$ & $70.2 \pm 5.4$ & $552.2 \pm 24.2$ & $317.3 \pm 12.3$ & $218.0 \pm 18.0$ & $52.0 \pm 7.6$ \\
\hline $\mathrm{HC}$ & $662.5 \pm 19.3$ & $72.7 \pm 9.5$ & $586.8 \pm 21.2$ & $330.2 \pm 19.5$ & $362.8 \pm 11.0^{*}$ & $121.8 \pm 10.5^{*}$ \\
\hline $\mathrm{HC}+\mathrm{AA} 1$ & $642.8 \pm 13.7$ & $69.4 \pm 8.8$ & $549.4 \pm 17.8$ & $341.0 \pm 15.0$ & $243.8 \pm 17.0^{* *}$ & $73.3 \pm 4.3^{* *}$ \\
\hline $\mathrm{HC}+\mathrm{AA} 2$ & $641.3 \pm 19.5$ & $67.93 \pm 7.2$ & $571.2 \pm 25.3$ & $309.4 \pm 15.6$ & $258.7 \pm 13.0^{* *}$ & $70.8 \pm 4.8^{* *}$ \\
\hline $\mathrm{HC}+\mathrm{QUE}$ & $642.2 \pm 15.0$ & $66.9 \pm 01.8$ & $558.7 \pm 18.2$ & $282 . \pm 24.8$ & $263.5 \pm 11.0^{* *}$ & $63.5 \pm 8.5$ \\
\hline QUE & $617.5 \pm 15.3$ & $69.3 \pm 10.5$ & $569.1 \pm 13.54$ & $274.0 \pm 11.3$ & $211.0 \pm 9.6$ & $60.4 \pm 7.6$ \\
\hline AA2 & $617.0 \pm 10.6$ & $67.0 \pm 7.9$ & $533.0 \pm 22.5$ & $312.2 \pm 17.4$ & $229.4 \pm 16.5$ & $64.0 \pm 6.6$ \\
\hline
\end{tabular}

Values are means \pm SD of 5 animals per group; HC: cholesterol at $30 \mathrm{mg} / 0.3 \mathrm{~mL}$.

AA1: Artocarpus altilis at $100 \mathrm{mg} / \mathrm{kg}$, AA2: Artocarpus altilis at $200 \mathrm{mg} / \mathrm{kg}$, and QUE: Questran at $0.26 \mathrm{~g} / \mathrm{kg}$.

${ }^{*}$ Significantly different from control $(P<0.05),{ }^{* *}$ significantly different from $\mathrm{HC}(P<0.05)$.

TABLE 6: Changes in serum lipid profile of hypercholesterolemic rats treated with methanol extract of Artocarpus altilis for nine weeks.

\begin{tabular}{lcccc}
\hline Treatment & Total chol. & $\begin{array}{c}\text { Triglyceride } \\
(\mathrm{mg} / \mathrm{dL})\end{array}$ & LDL-C & HDL-C \\
\hline Control & $325.07 \pm 7.71$ & $416.51 \pm 24.92$ & $211.40 \pm 9.03$ & $242.13 \pm 29.55$ \\
HC & $680.81 \pm 16.42^{*}$ & $701.77 \pm 18.63^{*}$ & $376.55 \pm 13.71^{*}$ & $150.39 \pm 32.49^{*}$ \\
HC + AA1 & $511.19 \pm 13.99^{* *}$ & $521.44 \pm 15.13^{* *}$ & $366.04 \pm 14.21$ & $110.15 \pm 14.00$ \\
HC + AA2 & $464.07 \pm 16.65^{* *}$ & $484.88 \pm 11.03^{* *}$ & $257.39 \pm 16.50^{* *}$ & $228.52 \pm 16.67^{* *}$ \\
HC + QUE & $378.71 \pm 12.59$ & $452.46 \pm 13.17$ & $308.28 \pm 10.95$ & $223.01 \pm 14.67$ \\
QUE & $411.33 \pm 16.72$ & $409.51 \pm 14.08$ & $298.72 \pm 16.19$ & $176.19 \pm 51.72$ \\
AA2 & $345.54 \pm 11.01$ & $438.69 \pm 18.63$ & $228.18 \pm 10.21$ & $242.78 \pm 17.18$ \\
\hline
\end{tabular}

Values are means \pm SD of 5 animals per group; HC: cholesterol at $30 \mathrm{mg} / 0.3 \mathrm{~mL}$.

AA1: Artocarpus altilis at $100 \mathrm{mg} / \mathrm{kg}, \mathrm{AA2}$ : Artocarpus altilis at $200 \mathrm{mg} / \mathrm{kg}$, and QUE: Questran at $0.26 \mathrm{~g} / \mathrm{kg}$,

${ }^{*}$ Significantly different from control $(P<0.05)$.

${ }^{* *}$ Significantly different from HC $(P<0.05)$.

TABLE 7: Changes in antiatherogenic, coronary risk, and cardioprotective indices of hypercholesterolemic rats treated with methanol extract of Artocarpus altilis and Questran for nine weeks.

\begin{tabular}{lccc}
\hline Treatment & & Serum & CPI \\
\hline Control & AAI $(\%)$ & CRI & $1.15 \pm 0.05$ \\
HC & $292.1 \pm 21.2$ & $1.34 \pm 0.03$ & $0.40 \pm 0.06^{*}$ \\
HC + AA1 & $28.0 \pm 3.7^{*}$ & $4.53 \pm 0.25^{*}$ & $0.30 \pm 0.05^{*}$ \\
HC + AA2 & $27.2 \pm 2.7^{*}$ & $4.65 \pm 0.43^{*}$ & $0.89 \pm 0.15^{* *}$ \\
HC + QUE & $116.1 \pm 17.3^{* *}$ & $1.86 \pm 0.17^{* *}$ & $0.72 \pm 0.08^{* *}$ \\
QUE & $143.0 \pm 21.8^{* *}$ & $1.70 \pm 0.22^{* *}$ & $0.83 \pm 0.10$ \\
AA2 & $149.1 \pm 12.1$ & $1.67 \pm 0.26$ & $1.06 \pm 0.41$ \\
\hline
\end{tabular}

HC: cholesterol at $30 \mathrm{mg} / 0.3 \mathrm{~mL}$, AA1: Artocarpus altilis at $100 \mathrm{mg} / \mathrm{kg}$,

AA2: Artocarpus altilis at $200 \mathrm{mg} / \mathrm{kg}$, QUE: questran at $0.26 \mathrm{~g} / \mathrm{kg}$,

antiatherogenic index (AAI): $100 \times[\mathrm{HDL}-\mathrm{C} /$ total cholesterol-HDL-C],

coronary risk index (CRI): total cholesterol/HDL-C,

cardioprotective index (CPI): HDL-C/LDL-C.

${ }^{*}$ Significantly different from control $(P<0.05),{ }^{* *}$ significantly different from $\mathrm{HC}(P<0.05)$.

atherogenic process, therapeutic intervention to raise HDL$\mathrm{C}$ together with other risk factors is widely encouraged. In this study, treatment with AA led to significant elevation of HDL-C, indicating its promising protective role against CVD. The protective roles of HDL-C from CVD have been suggested to occur in various ways [45]. HDL exerts part of its antiatherogenic effect by counteracting LDL oxidation and studies also showed that HDL promotes the reverse cholesterol transport pathway, by inducing an efflux of excess accumulated cellular cholesterol, and prevents the generation of an oxidatively modified LDL [46]. Furthermore, HDL not only inhibits the oxidation of LDL by transition metal ions but also prevents 12-lipoxygenase-mediated formation of lipid hydroperoxides [45]. On the basis of our results, AA may probably plays an antiatherogenic role through the inhibition of lipids oxidation, due to its antilipoperoxidative effect 


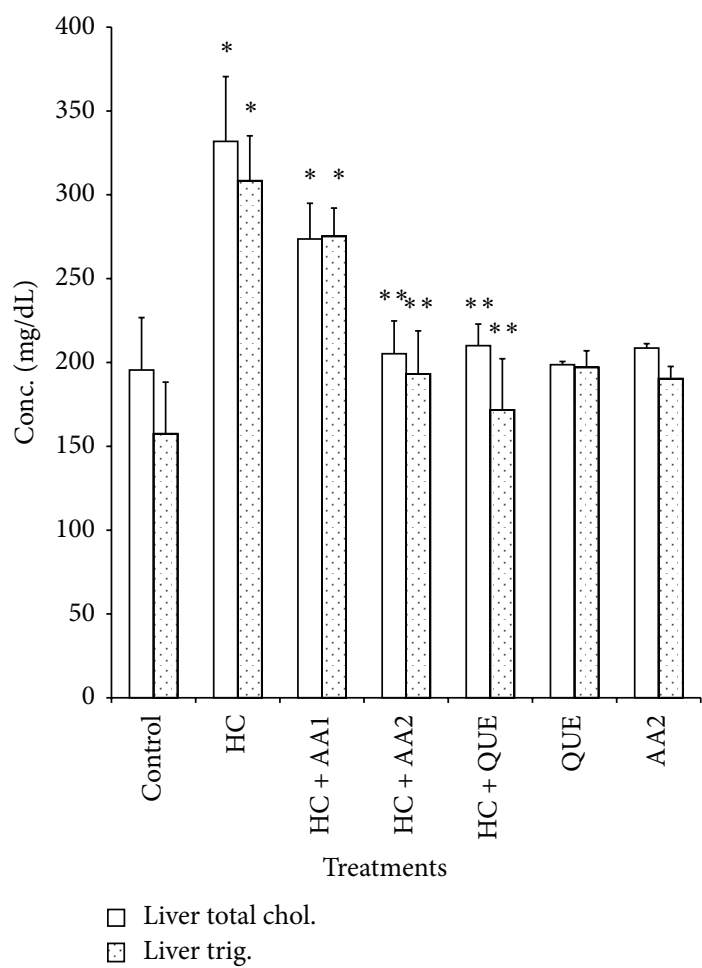

Figure 2: Effects of methanol extract of Artocarpus artilis and Questran on hepatic total cholesterol and triglyceride levels of hypercholesterolemic rats. * Significantly different from control $(P<$ $0.05),{ }^{* *}$ significantly different from HC $(P<0.05)$. HC: hypercholesterolemic rats, AA1: Artocarpus altilis at $100 \mathrm{mg} / \mathrm{kg}$, AA2: Artocarpus altilis at $200 \mathrm{mg} / \mathrm{kg}$, and QUE: Questran at $0.26 \mathrm{~g} / \mathrm{kg}$.

observed in this study as well as the elevation of HDL-C. LDLC, another primary target of CVD risk reduction therapy [41]. In this study, AA administered at a dose of $200 \mathrm{mg} / \mathrm{kg}$ lowered LDL-C levels of hypercholesterolemic rats. It is known that excess of LDL can be deposited on the blood vessel walls and becomes a major component of atherosclerotic plaque lesions. Therefore, serum LDL-C level has been used to monitor treatment of patients with elevated blood cholesterol levels. In view of our results, AA elicited beneficial effects by lowering serum total cholesterol including low-density lipoprotein of the hypercholesterolemic rats. In addition, hypocholesterolemic and hypotriglyceridemic effects of AA may probably be due to the inhibition of rate-limiting enzyme 3-hydroxy-3-methyl glutaryl CoA reductase (HMG-CoA reductase) of cholesterol biosynthesis. The experimentally obtained hypotriglyceridemic effect of AA may also be due to the improvement in lipolysis by reducing the activity of hormone-sensitive lipase [42]. To further support the lipid lowering potential of $\mathrm{AA}$, the antiatherogenic index (AAI) was also evaluated and found to increase in $\mathrm{HC}$ rats treated with AA as compared to controls. Similarly, improvement was also observed in cardioprotective index (CPI) of $\mathrm{HC}$ rats treated with $\mathrm{AA}$ in terms of $\mathrm{HDL}-\mathrm{C} / \mathrm{LDL}-\mathrm{C}$ ratio relative to controls. Out of the risk indices considered, HDL-C/LDL$\mathrm{C}$ ratio (CPI) was found ideal in the present study. It has been reported that a decrease in HDL-C/LDL-C ratio is

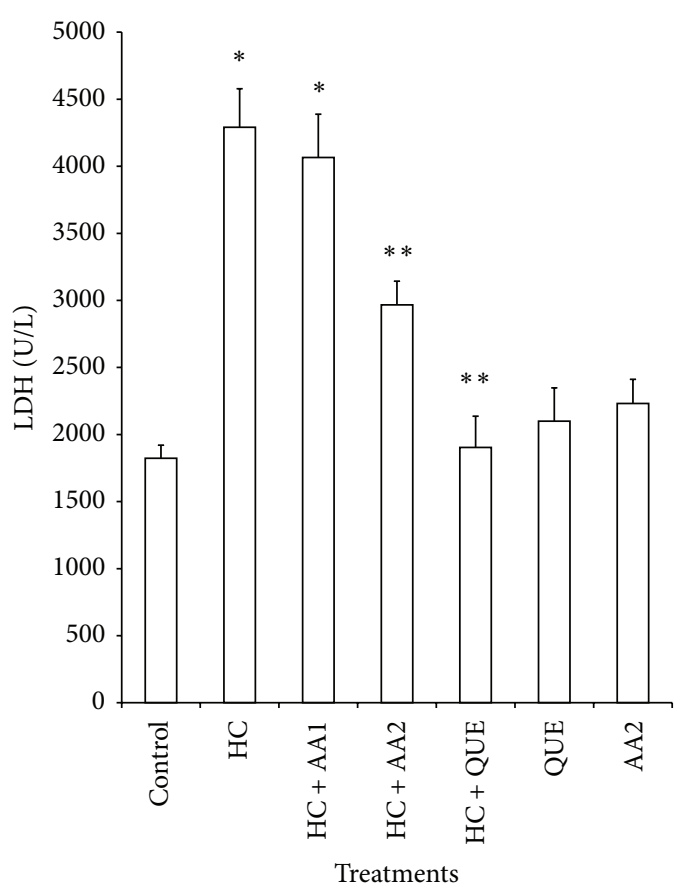

FIGURE 3: Effects of methanol extract of Artocarpus artilis on the activities of serum lactate dehydrogenase (LDH) of hypercholesterolemic rats. ${ }^{*}$ Significantly different from control $(P<0.05)$, ${ }^{* *}$ significantly different from HC $(P<0.05)$. HC: hypercholesterolemic rats, AA1: Artocarpus altilis at $100 \mathrm{mg} / \mathrm{kg}$, AA2: Artocarpus altilis at $200 \mathrm{mg} / \mathrm{kg}$, and QUE: Questran at $0.26 \mathrm{~g} / \mathrm{kg}$.

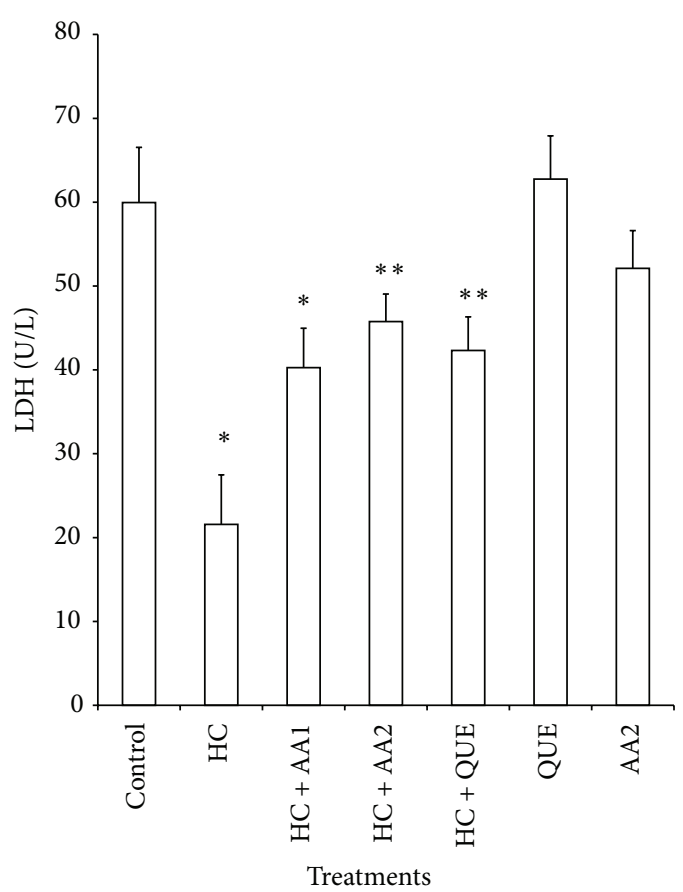

FIgURE 4: Effects of methanol extract of Artocarpus artilis on the activities of cardiac lactate dehydrogenase (LDH) of hypercholesterolemic rats. ${ }^{*}$ Significantly different from control $(P<0.05)$, ${ }^{* *}$ significantly different from HC $(P<0.05)$. HC: hypercholesterolemic rats, AA1: Artocarpus altilis at $100 \mathrm{mg} / \mathrm{kg}$, AA2: Artocarpus altilis at $200 \mathrm{mg} / \mathrm{kg}$, and QUE: Questran at $0.26 \mathrm{~g} / \mathrm{kg}$. 


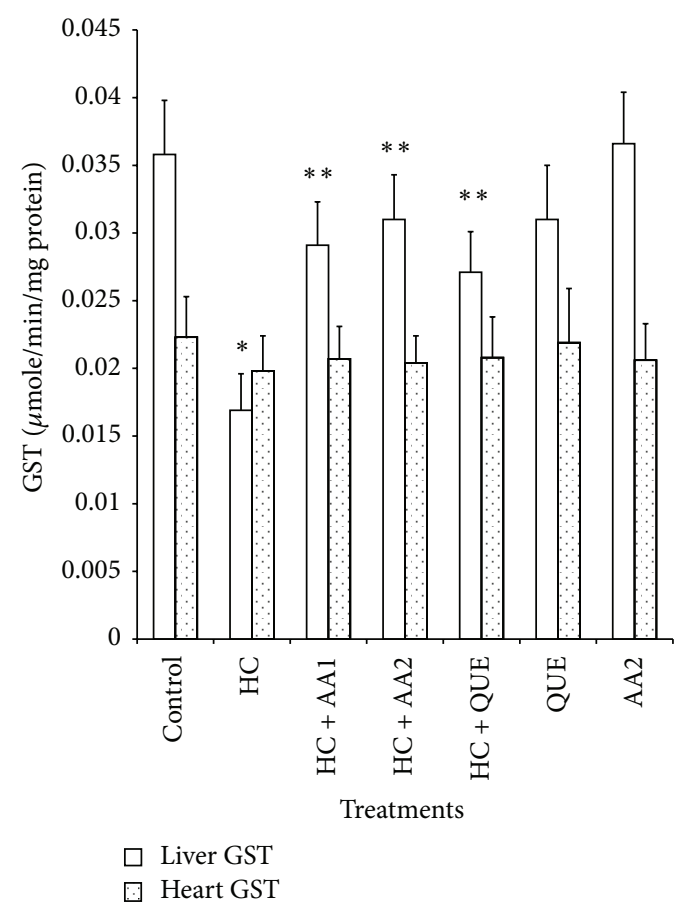

FIGURE 5: Effects of methanol extract of Artocarpus artilis on the activities of hepatic and cardiac glutathione-s-transferase (GST) of hypercholesterolemic rats. ${ }^{*}$ Significantly different from control $(P<0.05)$, ${ }^{* *}$ significantly different from HC $(P<0.05)$. HC: hypercholesterolemic rats, AA1: Artocarpus altilis at $100 \mathrm{mg} / \mathrm{kg}$, AA2: Artocarpus altilis at $200 \mathrm{mg} / \mathrm{kg}$, and QUE: Questran at $0.26 \mathrm{~g} / \mathrm{kg}$.

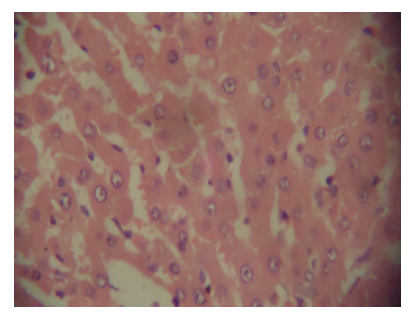

Control

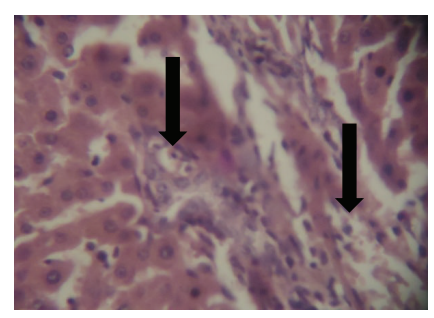

HC

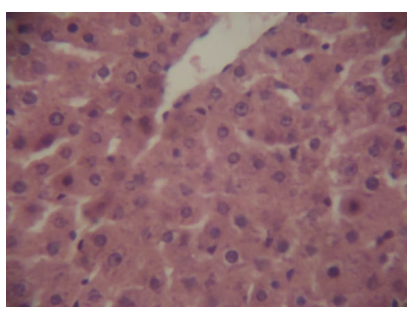

$\mathrm{HC}+\mathrm{AA} 1$

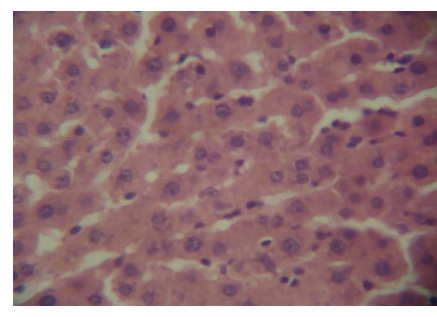

$\mathrm{HC}+\mathrm{AA} 2$

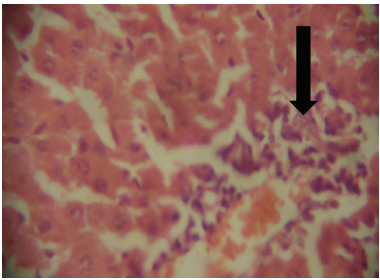

$\mathrm{QUE}+\mathrm{AA} 2$

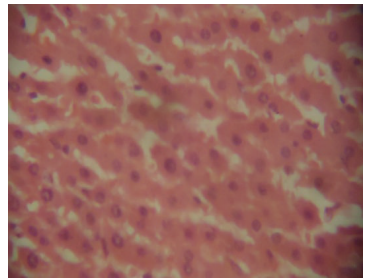

QUE

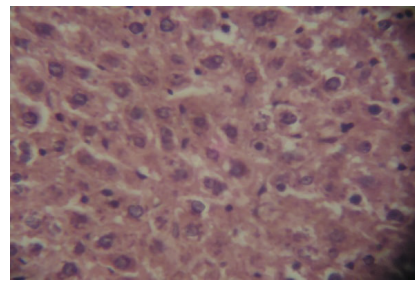

AA2

FIGURE 6: Changes in histology of liver samples of hypercholesterolemic rats treated with Artocarpus altilis and Questran for nine consecutive weeks $(\mathrm{M} \times 400)$. HC: cholesterol at $30 \mathrm{mg} / 0.3 \mathrm{~mL}$, AA1: Artocarpus altilis at $100 \mathrm{mg} / \mathrm{kg}$, AA2: Artocarpus altilis at $200 \mathrm{mg} / \mathrm{kg}$, and QUE: Questran at $0.26 \mathrm{~g} / \mathrm{kg}$. Black arrow shows portal congestion, periportal cellular infiltration, and vacuolar degeneration of hepatocytes.

good predictor of CVD in subjects [47]. Similarly, coronary risk index (CRI) in terms of TC/HDL-C ratio significantly decreased in AA-treated $\mathrm{HC}$ rats, which further strengthen the beneficial effects of AA.

Serum AST and ALT are the reliable markers for liver function, while serum LDH may give information on the state of the cardiac tissue. It is established that AST can be found in the liver, cardiac muscle, skeletal muscle, and so forth, whereas ALT is predominantly present in the liver [48]. The increased levels of serum AST and ALT in HC rats indicate an increased permeability and damage and/or necrosis of hepatocytes. Similar results were reported by Suk et al. [49] and Mohd Esa et al. [50] in which ALT and AST activities were elevated in $\mathrm{HC}$ rats. In our study, we found that extract 


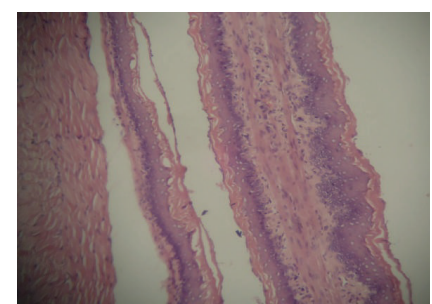

Control

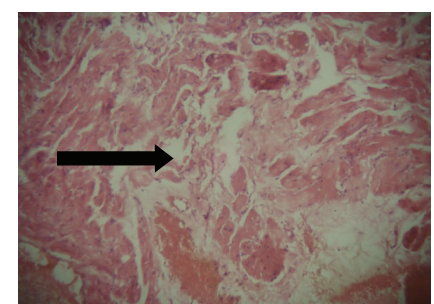

$\mathrm{HC}$

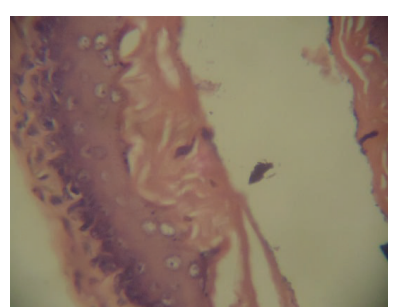

$\mathrm{HC}+\mathrm{AA} 1$

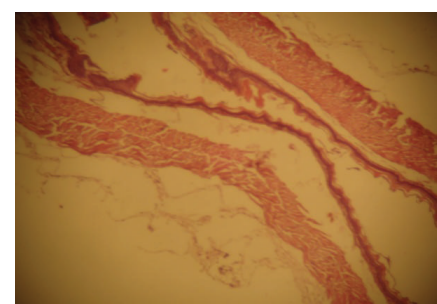

$\mathrm{HC}+\mathrm{AA} 2$

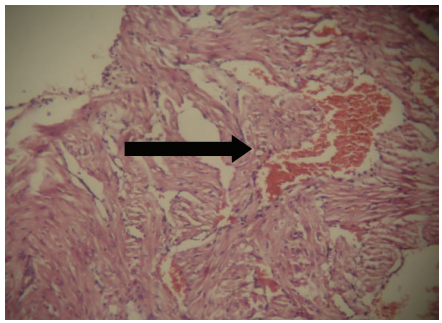

$\mathrm{HC}+\mathrm{QUE}$

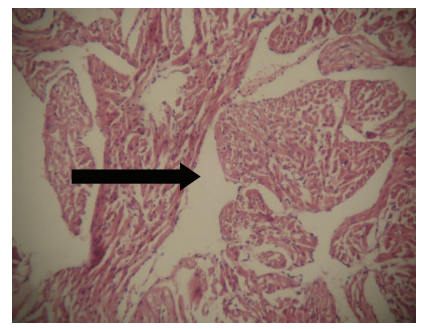

QUE

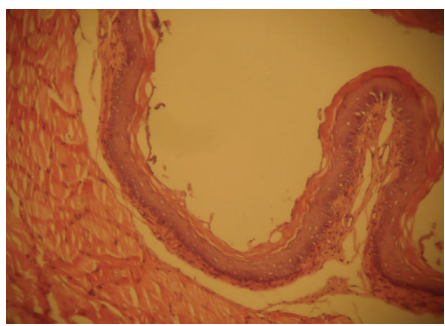

AA2

FIGURE 7: Changes in histology of aorta from hypercholesterolemic rats treated with Artocarpus altilis and Questran for nine consecutive weeks $(\mathrm{M} \times 400)$. HC: cholesterol at $30 \mathrm{mg} / 0.3 \mathrm{~mL}$, AA1: Artocarpus altilis at $100 \mathrm{mg} / \mathrm{kg}$, AA2: Artocarpus altilis at $200 \mathrm{mg} / \mathrm{kg}$, and QUE: Questran at $0.26 \mathrm{~g} / \mathrm{kg}$. Black arrows shows myofibril necrosis, severe hemorrhages, and fibrous connective tissue laid down.

of AA at a dose of $200 \mathrm{mg} / \mathrm{kg}$ caused a significant reduction in the activities of serum AST, ALT, and LDH, which further supports the beneficial effects of the extract of AA in $\mathrm{HC}$ rats.

Oxidative stress, defined as a disruption of the balance between oxidative and antioxidative processes, plays an important role in the pathogenesis of atherosclerosis [51]. Studies in animal models and human clinical trials have established a relationship between hypercholesterolemia and lipid peroxidation [50]. In agreement with these findings, our results show increased levels of MDA in the serum and tissues of $\mathrm{HC}$ rats when compared to controls. On the other hand, treatment with AA caused a significant reduction in the levels of MDA in these organs. This protective effect is probably based on the antioxidant activity of $\mathrm{AA}$, which reduced the oxidative damage by blocking the production of free radicals and thus inhibited lipid peroxidation. In this study, we also observed a significant decrease in the activities of free radical scavenging enzymes, SOD and CAT, which are the first line of defence against oxidative injury. The inhibition of antioxidant system (SOD and CAT) may cause the accumulation of $\mathrm{H}_{2} \mathrm{O}_{2}$ or products of its decomposition [52]. SOD catalyzes the conversion of superoxide anion into $\mathrm{H}_{2} \mathrm{O}_{2}$. The primary role of CAT is to scavenge $\mathrm{H}_{2} \mathrm{O}_{2}$ that has been generated by free radical or by SOD. Importantly, administration of AA restored the activities of enzymatic antioxidants (SOD and CAT) in liver and heart of $\mathrm{HC}$ rats. AA may therefore act as an effective antioxidant of great importance against diseases and degenerative processes caused by oxidative stress. Our results showed that the extract of AA at $750 \mu \mathrm{g} / \mathrm{mL}$ produced $63 \%$ inhibition of DPPH radical relative to catechin (68\%). The antioxidant property of AA may be linked to high polyphenolic compounds in this plant as shown in our results. From these findings, AA positively modulates the antioxidant redox status of $\mathrm{HC}$ rats, in addition to its beneficial effects on the lipid profile.

\section{Conclusion}

The present study suggests that Artocarpus altilis has potent blood and tissues lipid-lowering capability. In addition, it has significant antiatherogenic effect and also improves antioxidant system of hypercholesterolemic rats. Further studies are required to identify the active component(s) and mechanism(s) underlying the beneficial effects of this plant.

\section{Conflict of Interests}

The authors declare that they have no conflict of interests.

\section{Acknowledgments}

This research was partly supported by Senate Research Grants from University of Ibadan, Nigeria Oluwatosin Adekunle given to Dr. Oluwatosin Adekunle Adaramoye (SRG/ COM/2010/7A).

\section{References}

[1] P. Kresanov, M. Ahotupa, T. Vasankari et al., "The associations of oxidized high-density lipoprotein lipids with risk factors for atherosclerosis: the cardiovascular risk in young finns study," Free Radical Biology and Medicine C, vol. 65, pp. 1284-1290, 2013.

[2] K. Kovács, K. Erdélyi, C. Hegedűs et al., "Poly(ADP-ribosyl)ation is a survival mechanism in cigarette smoke-induced and hydrogen peroxide-mediated cell death," Free Radical Biology and Medicine, vol. 53, no. 9, pp. 1680-1688, 2012.

[3] G. Sikka, D. Pandey, A. K. Bhuniya et al., "Contribution of arginase activation to vascular dysfunction in cigarette smoking," Atherosclerosis, vol. 231, no. 1, pp. 91-94, 2013. 
[4] M. Füzi, Z. Palicz, J. Vincze et al., "Fluvastatin-induced alterations of skeletal muscle function in hypercholesterolaemic rats," Journal of Muscle Research and Cell Motility, vol. 32, no. 6, pp. 391-401, 2012.

[5] N. A. Salem and E. A. Salem, "Renoprotective effect of grape seed extract against oxidative stress induced by gentamicin and hypercholesterolemia in rats," Renal Failure, vol. 33, no. 8, pp. 824-832, 2011.

[6] T. Rantanen, "Midlife fitness predicts less burden of chronic disease in later life," Clinical Journal of Sport Medicine, vol. 23, no. 6, pp. 499-500, 2013.

[7] J. A. Borke and P. C. Wyer, "Eating a larger number of highsalt foods is not associated with short-term risk of acute decompensation in patients with chronic heart failure," The Journal of Emergency Medicine, vol. 44, no. 1, pp. 36-45, 2013.

[8] R. Schekman, "Discovery of the cellular and molecular basis of cholesterol control," Proceedings of the National Academy of Sciences of the United States of America, vol. 110, no. 37, pp. 14833-14836, 2013.

[9] C. A. Miller, "Update on statins and other lipid-lowering drugs," Geriatric Nursing, vol. 22, no. 5, pp. 276-277, 2001.

[10] A. M. Rincón, L. B. Rached, L. E. Aragoza, and F. Padilla, "Effect of acetylation and oxidation on some properties of Breadfruit (Artocarpus altilis) seed starch," Archivos Latinoamericanos de Nutricion, vol. 57, no. 3, pp. 287-294, 2007.

[11] N. J. C. Zerega, D. Ragone, and T. J. Motley, "Systematics and species limits of breadfruit (Artocarpus moraceae)," Systematic Botany, vol. 30, no. 3, pp. 603-615, 2005.

[12] C. A. Lans, "Ethnomedicines used in Trinidad and Tobago for urinary problems and diabetes mellitus," Journal of Ethnobiology and Ethnomedicine, vol. 2, pp. 45-56, 2006.

[13] C. R. Nwokocha, D. U. Owu, M. McLaren et al., "Possible mechanisms of action of the aqueous extract of Artocarpus altilis (breadfruit) leaves in producing hypotension in normotensive Sprague-Dawley rats," Pharmaceutical Biology, vol. 50, no. 9, pp. 1096-1102, 2012.

[14] V. L. Singleton, R. Orthofer, and R. M. Lamuela-Raventós, "Analysis of total phenols and other oxidation substrates and antioxidants by means of folin-ciocalteu reagent," Methods in Enzymology, vol. 299, no. 1, pp. 152-178, 1998.

[15] L. I. Mensor, F. S. Menezes, G. G. Leitao et al., "Screening of Brazilian plant extracts for antioxidant activity by the use of DPPH free radical method," Phytotherapy Research, vol. 15, no. 2, pp. 127-130, 2001.

[16] O. A. Adaramoye, V. O. Nwaneri, K. C. Anyanwo, E. O. Farombi, and G. O. Emerole, "Possible anti-atherogenic effect of kolaviron (a Garcinia kola seed extract) in hypercholesterolaemic rats," Clinical and Experimental Pharmacology and Physiology, vol. 32, no. 1-2, pp. 40-46, 2005.

[17] O. H. Lowry, N. J. Rosebrough, A. L. Farr, and R. J. Randall, "Protein measurement with the Folin phenol reagent," The Journal of Biological Chemistry, vol. 193, no. 1, pp. 265-275, 1951.

[18] A. F. Mohun and I. J. Cook, "Simple methods for measuring serum levels of the glutamic-oxalacetic and glutamic-pyruvic transaminases in routine laboratories," Journal of Clinical Pathology, vol. 10, no. 4, pp. 394-399, 1957.

[19] S. Reitman and S. Frankel, "A colorimetric method for the determination of serum glutamic oxalacetic and glutamic pyruvic transaminases," American Journal of Clinical Pathology, vol. 28, no. 1, pp. 56-63, 1957.
[20] W. Richmond, "Preparation and properties of a cholesterol oxidase from Nocardia sp. and its application to the enzymatic assay of total cholesterol in serum," Clinical Chemistry, vol. 19, no. 12, pp. 1350-1356, 1973.

[21] N. J. Jacobs and P. J. van Demark, “The purification and properties of the $\alpha$-glycerophosphate-oxidizing enzyme of Streptococcus faecalis 10C1," Archives of Biochemistry and Biophysics, vol. 88, no. 2, pp. 250-255, 1960.

[22] L. K. Koditschek and W. W. Umbreit, "Alpha-glycerophosphate oxidase in Streptococcus faecium F 24," Journal of Bacteriology, vol. 98, no. 3, pp. 1063-1068, 1969.

[23] W. T. Friedewald, R. I. Levy, and D. S. Fredrickson, "Estimation of the concentration of low-density lipoprotein cholesterol in plasma, without use of the preparative ultracentrifuge," Clinical Chemistry, vol. 18, no. 6, pp. 499-502, 1972.

[24] J. A. Buege and S. D. Aust, "Microsomal lipid peroxidation," Methods in Enzymology, vol. 52, pp. 302-310, 1978.

[25] H. J. Zimmerman and H. G. Weinstein, "Lactic dehydrogenase activity in human serum," The Journal of Laboratory and Clinical Medicine, vol. 48, no. 2, pp. 607-609, 1956.

[26] J. M. McCord and I. Fridovich, "Superoxide dismutase. An enzymic function for erythrocuprein (hemocuprein)," The Journal of Biological Chemistry, vol. 244, no. 22, pp. 6049-6055, 1969.

[27] H. Aebi, "Catalase estimation," in Methods of Enzymatic Analysis, H. V. Bergmeyer, Ed., pp. 673-684, Verlag Chemic, New York, NY, USA, 1974.

[28] E. Beutler, O. Duron, and B. M. Kellin, "Improved method for the determination of blood glutathione," The Journal of Laboratory and Clinical Medicine, vol. 61, pp. 882-888, 1963.

[29] J. T. Rotruck, A. L. Pope, H. E. Ganther, A. B. Swanson, D. G. Hafeman, and W. G. Hoekstra, "Selenium: biochemical role as a component of glatathione peroxidase," Science, vol. 179, no. 4073, pp. 588-590, 1973.

[30] W. H. Habig, M. J. Pabst, and W. B. Jakoby, "Glutathione $S$ transferases. The first enzymatic step in mercapturic acid formation," The Journal of Biological Chemistry, vol. 249, no. 22, pp. 7130-7139, 1974.

[31] P. Barter, A. M. Gotto, J. C. LaRosa et al., "HDL cholesterol, very low levels of LDL cholesterol, and cardiovascular events," The New England Journal of Medicine, vol. 357, no. 13, pp. 1301-1310, 2007.

[32] H.-T. Kang, J.-K. Kim, J.-Y. Kim, J. A. Linton, J.-H. Yoon, and S.B. Koh, "Independent association of TG/HDL-C with urinary albumin excretion in normotensive subjects in a rural Korean population," Clinica Chimica Acta, vol. 413, no. 1-2, pp. 319-324, 2012.

[33] A. A. Adeneye and J. A. Olagunju, "Preliminary hypoglycaemic and hypolipidemic activities of the aqueous seed extract of Carica papaya Linn. in Wistar rats," Biology and Medicine, vol. 1, no. 1, pp. 1-10, 2009.

[34] M. A. Waqar and Y. Mahmmod, "Anti-platelet, antihypercholesterolemia and anti-oxidant effects of Ethanolic extract of Brassica oleracea in high fat diet provided rats," World Applied Sciences Journal, vol. 8, no. 1, pp. 107-112, 2010.

[35] S. Paolillo, G. L. Della Ratta, A. Vitagliano et al., "New perspectives in cardiovascular risk reduction: focus on HDL," Archives for Chest Disease, vol. 80, no. 1, pp. 27-30, 2013.

[36] S. C. Smith Jr., E. J. Benjamin, R. O. Bonow et al., "AHA/ACCF secondary prevention and risk reduction therapy for patients with coronary and other atherosclerotic vascular disease," Circulation, vol. 124, no. 22, pp. 2458-2473, 2011. 
[37] Ž. Reiner, A. L. Catapano, G. de Backer et al., "ESC/EAS Guidelines for the management of dyslipidaemias," European Heart Journal, vol. 32, no. 14, pp. 1769-1818, 2011.

[38] K. Yuji, H. Sakaida, T. Kai et al., "Effect of dietary blueberry (Vaccinium ashei Reade) leaves on serum and hepatic lipid levels in rats," Journal of Oleo Science, vol. 62, no. 2, pp. 89-96, 2013.

[39] O. A. Adaramoye, O. Akintayo, J. Achem, and M. A. Fafunso, "Lipid-lowering effects of methanolic extract of Vernonia amygdalina leaves in rats fed on high cholesterol diet," Vascular Health and Risk Management, vol. 4, no. 1, pp. 235-241, 2008.

[40] V. Kamesh and T. Sumathi, "Antihypercholesterolemic effect of Bacopa monniera linn. on high cholesterol diet induced hypercholesterolemia in rats," Asian Pacific Journal of Tropical Medicine, vol. 5, no. 12, pp. 949-955, 2012.

[41] P. O. Kwiterovich Jr., "The metabolic pathways of high-density lipoprotein, low-density lipoprotein, and triglycerides: a current review," American Journal of Cardiology, vol. 86, no. 12, pp. 5-10, 2000.

[42] M. L. Bishop, E. P. Fody, and L. Schoeff, Clinical Chemistry: Principles, Procedures, Correlations, Lippincott Williams \& Wilkins, 6th edition, 2010.

[43] S. A. Qureshi, M. Kamran, M. Asad, A. Zia, T. Lateef, and M. B. Azmi, "A preliminary study of Santalum album on serum lipids and enzymes," Global Journal of Pharmacology, vol. 4, no. 2, pp. 71-74, 2010.

[44] T. D. Filippatos and M. S. Elisaf, "High density lipoprotein and cardiovascular diseases," World Journal of Cardiology, vol. 5, no. 7, pp. 210-214, 2013.

[45] J.-R. Nofer, B. Kehrel, M. Fobker, B. Levkau, G. Assmann, and A. V. Eckardstein, "HDL and arteriosclerosis: beyond reverse cholesterol transport," Atherosclerosis, vol. 161, no. 1, pp. 1-16, 2002.

[46] T. Yokozawa, E. J. Cho, S. Sasaki, A. Satoh, T. Okamoto, and Y. Sei, "The protective role of Chinese prescription Kangen-karyu extract on diet-induced hypercholesterolemia in rats," Biological and Pharmaceutical Bulletin, vol. 29, no. 4, pp. 760-765, 2006.

[47] T. Marotta, B. F. Russo, and L. A. Ferrara, "Triglyceride-toHDL-cholesterol ratio and metabolic syndrome as contributors to cardiovascular risk in overweight patients," Obesity, vol. 18, no. 8, pp. 1608-1613, 2010.

[48] R. Rej, "Liver diseases and the clinical laboratory-the twentieth Arnold O. Beckman conference in clinical chemistry," Clinical Chemistry, vol. 43, no. 8, pp. 1473-1475, 1997.

[49] F.-M. Suk, S.-Y. Lin, C.-H. Chen et al., "Taiwanofungus camphoratus activates peroxisome proliferator-activated receptors and induces hypotriglyceride in hypercholesterolemic rats," Bioscience, Biotechnology and Biochemistry, vol. 72, no. 7, pp. 1704-1713, 2008.

[50] N. Mohd Esa, K. K. Abdul Kadir, Z. Amom, and A. Azlan, "Antioxidant activity of white rice, brown rice and germinated brown rice (in vivo and in vitro) and the effects on lipid peroxidation and liver enzymes in hyperlipidaemic rabbits," Food Chemistry, vol. 141, no. 2, pp. 1306-1312, 2013.

[51] A. V. Rzheshevsky, "Fatal, "triad": lipotoxicity, oxidative stress, and phenoptosis," Biochemistry, vol. 78, no. 9, pp. 991-1000, 2013.

[52] C. E. Cross, A. van der Vliet, C. A. O’Neill, S. Louie, and B. Halliwell, "Oxidants, antioxidants, and respiratory tract lining fluids," Environmental Health Perspectives, vol. 102, no. 10, pp. 185-191, 1994. 

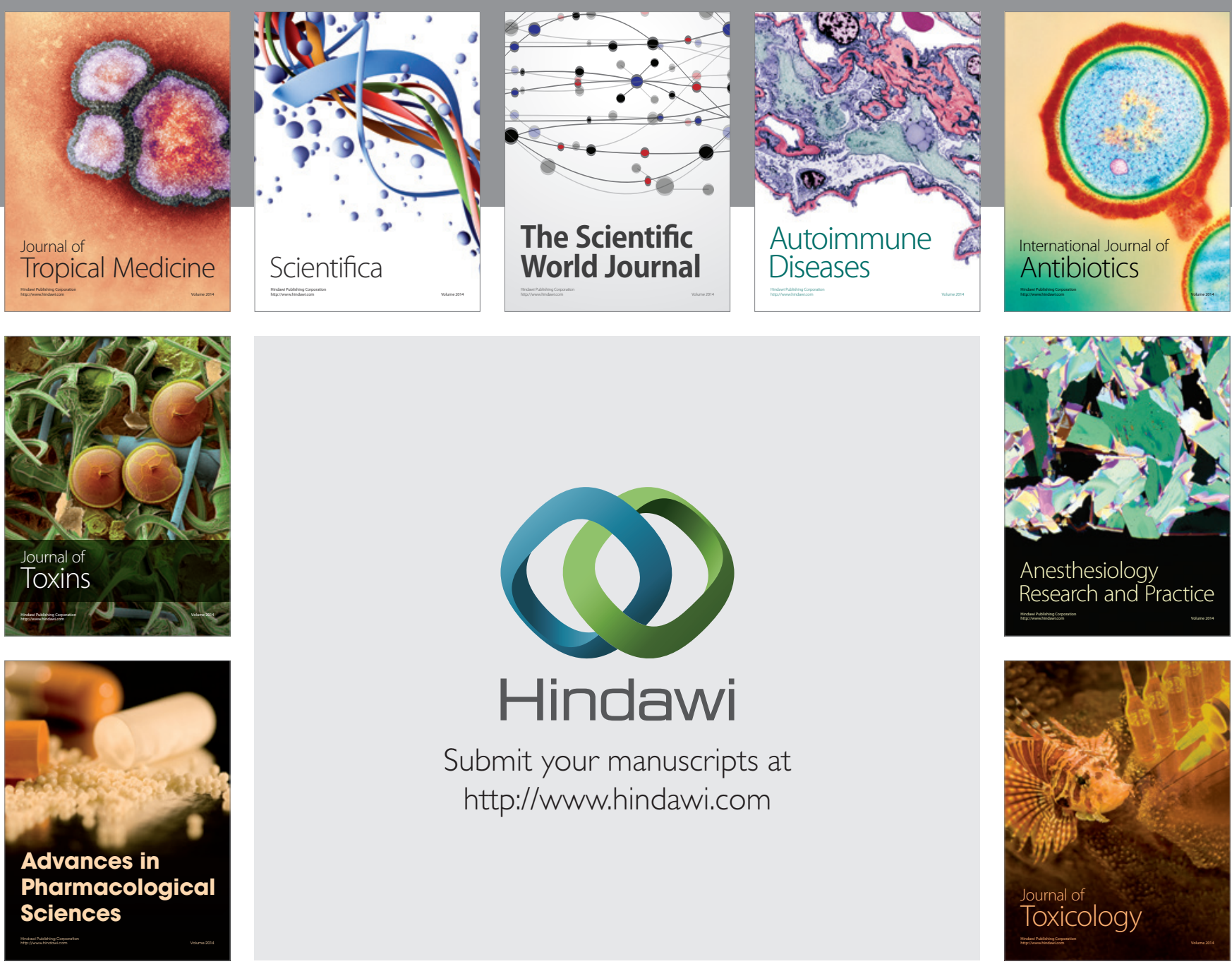

\section{Hindawi}

Submit your manuscripts at

http://www.hindawi.com
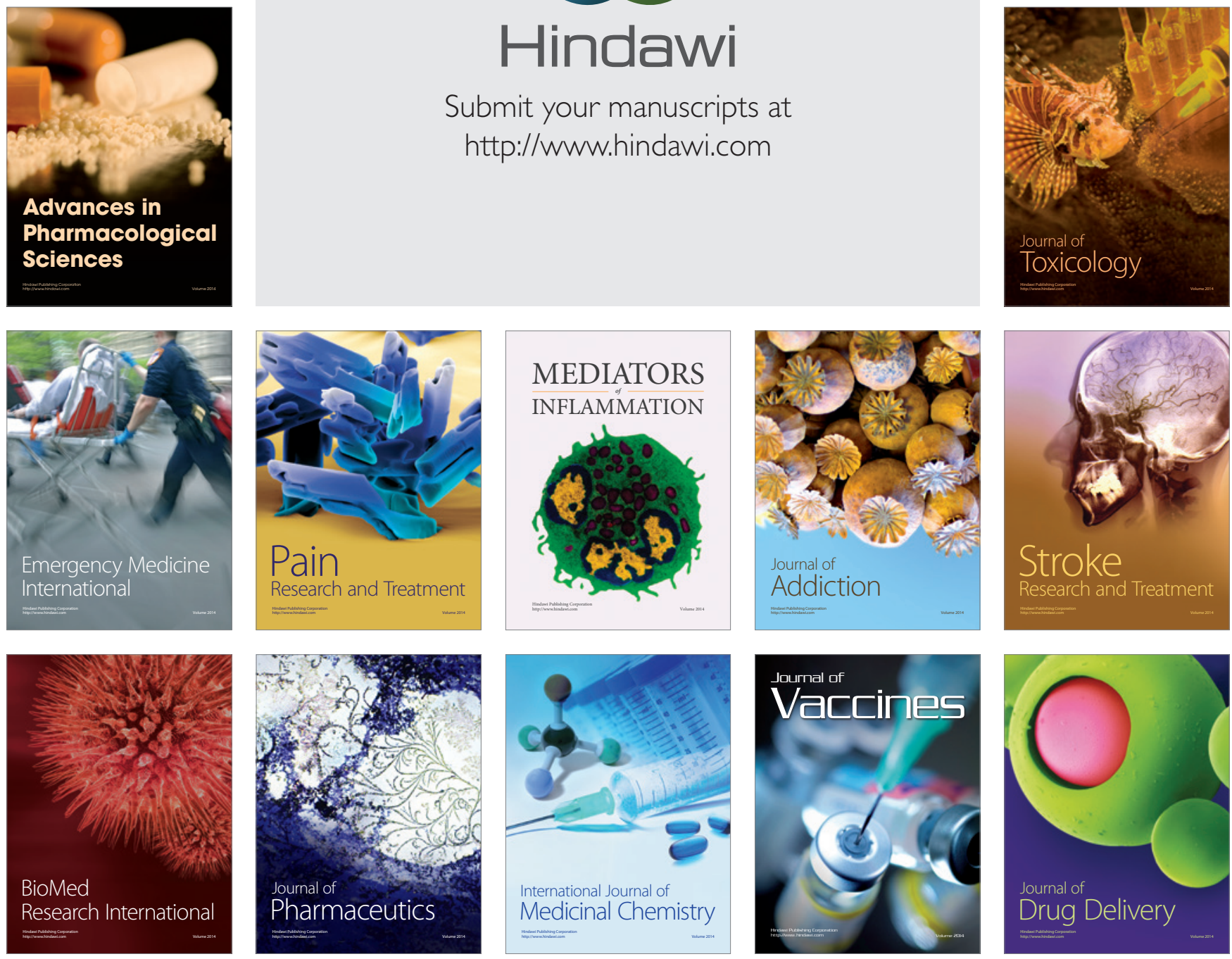